\title{
An Analysis of the Possible Economic Effects of HIV/AIDS in Swaziland Using the SAM and CGE Models
}

\author{
Mphumuzi Angelbert Sukati \\ University of Nottingham, Nottingham, Britain
}

\begin{abstract}
This is a conceptual paper which was motivated by the fact that Swaziland does not have a Social Accounting Matrix (SAM) in place and as such there are many shocks that affect that country’s economy but which cannot be analyzed effectively. Most notable of this is the economic effects of the HIV/AIDS scourge that is affecting that country of which it has been difficult to determine the effects it has had on the economy in an objective manner. This paper will highlight the usefulness of the SAM and Computable General Equilibrium (CGE) models in analyzing the possible economic effects of HIV/AIDS in Swaziland. The absence of a SAM for Swaziland means that empirical analysis of the effect of the disease on the economy could not be undertaken, but it is hoped that the arguments presented here will contribute to the use of these methods as tools for analyzing various shocks in an economy. The paper is divided into 4 parts. Part 1 is a brief introduction into the Swaziland economy, part 2 is a brief description of the SAM, description of CGE Modeling and a detailed application of the SAM data into the CGE modeling framework, part 3 introduces the HIV/AIDS situation in Swaziland and models its possible effects using a macroeconomic SAM and part 4 is the discussion and conclusion. The main aim of the paper then is to lay the basic framework to help small developing countries develop practical SAMs that will become an important tool in analyzing the performances of their economies.
\end{abstract}

Keywords: CGE Model, HIV/AIDS, SAM

\section{Introduction}

Swaziland is a small land locked country $\left(17,364 \mathrm{~km}^{2}\right)$ located in Southern Africa. It has a population of about 1 million of which 75\% live in rural areas (1997 census and Central Statistics Office, 2000). The majority of Swazis are poor although the country is classified as middle income. About $75 \%$ of land is Swazi Nation Land (SNL) held in trust by the King and the rest is Title Deed Land (TDL). Agriculture is very important for the Swazi economy and sustains most rural livelihoods. Important agricultural activities are for sugar cane, maize and livestock.

Swaziland has one of the highest prevalence rates of HIV/AIDS in the world, and this has exerted major strains in the economy of the country that is struggling with low food productivity from adverse weather conditions and subsistence based farming methods. This means that Swaziland remains a net food importer.

South Africa is Swaziland's main trading partner, and the two countries share a common monetary policy where the Swazi Lilangeni ${ }^{1}$ is pegged at par with the South African Rand. According to Food and Agriculture

Mphumuzi Angelbert Sukati, Ph.D. candidate, School of Economics, University of Nottingham.

${ }^{1}$ Lilangeni (plural = Emalangeni) is the Swazi currency pegged at about 1 US dollar to 7.2 Emalangeni. 
Organization (of the United Nations) (FAO) (2009) South Africa accounts for $80 \%$ of Swazi imports and 74\% of exports ${ }^{2}$.

\section{Description of the SAM}

\section{The Social Accounting Matrix (SAM)}

The SAM is an important economic tool to analyze the effect of a policy change or shocks that affect certain factors in an economy. It describes the full circular flow of money and goods in an economy and can be viewed as a data gathering framework that can then be used as an analytical tool for studying the effects of various macroeconomic policies as well as the impact of sectoral growth on poverty alleviation (Khan, 2007). Viewed as such, the SAM can be applicable to a wide range of situations if it is well understood and it basically throws in the bigger picture of a certain economic change in a ripple effect manner. However, a SAM is not an economic model although the structure of a SAM has a Keynesian flavor, reflecting its origins in Leontief's input-output schema and Keynesian macroeconomics (McDonald, Kirsten, \& Van Zyl, 1997). It is thus important that each country develops a SAM and updates it from time to time in order to analyze changes in the economy. The arrangement of a SAM is that the rows and columns represent receipt and expenditure accounts respectively of economic actors (Alderman, 1986). When combined with the Computable General Equilibrium Model (CGE Model) with which they share the similar equilibrium solution outcomes, the SAM can be a powerful yet user friendly tool to analyze the economy.

\section{The Computable General Equilibrium (CGE) Model}

The CGE Model as its name suggests aims to determine a point in a market or where supply equals demand. This is the basic law of the Walrasian equilibrium which states simply that markets clear at this point of equilibrium where supply equals demand. The aim of the model then is to solve for the prices that will prevail at that equilibrium point. In the Walrasian equilibrium models, the flexible price vector determines the equilibrium while in the Keynesian equilibrium model in the short-run the quantities vary while the price remain fixed (Khan, 2007).

The following is the description of the SAM and CGE modeling as detailed by Wing (2003). Firstly, he noted that CGE models result in black box outcomes since they contain complicated formula with many variables which make it difficult to pinpoint the effects specifically of the economic factor under study. However, this is exactly their usefulness since, combined with the SAM, they aim to throw in the general picture of the effect of an economic change like changes in policy in a ripple effect, thus useful conclusions can be drawn from their application. The CGE model is based on the flow of goods and services in a closed economy.

Households are both producers and consumers of commodities, and firms pay the households in order to use their factors of production to produce goods and services that are in turn consumed by the households. A third party may be added in this scenario, e.g., the government which can act as harmonizing the flow of commodities between the firms and households through the use of taxes and other policies that smooth this flow.

Households then rent capital and labor to firms who produce the commodities that are in turn "rented" by the households for the purposes of their everyday lives. Thus seen in this light, the CGE is basically a zero sum game and that is the reason that enables it to have a unique solution in prices and allocation of goods and the

\footnotetext{
${ }^{2}$ It is interesting to determine how this trade balance with South Africa will be affected by the current Economic Partnership Agreements (EPA) with the European Union (EU).
} 
factors of production. This zero sum game scenario means that markets clear, households maximize utility under a budgetary constraint (i.e., the payments they receive from firms for their factors of production) and firms maximize profits, which are driven down to zero.

The CGE model therefore must express this flow of commodities in some value terms and that is why they solve for relative prices from a certain fixed point called the numeraire good.

\section{The SAM and the Algebraic Equilibrium}

To motivate the SAM, considering a closed free market economy composed of $N$ industries each of which is a producer of commodities and an unspecified number of households that have $F$ factors of production which is their endowment.

In this case, an economy without distortions is considered and the households are considered in aggregation. The households then purchase the $N$ commodities produced by the firms to satisfy their demand $D$. In this case, each industry acts as a representive firm that hires inputs of the $F$ primary factors and uses quantities of the $N$ commodities as intermediate inputs to produce a quantity $y$ of its own type of output.

Thus, let:

$i=\{1, \ldots, \mathrm{N}\}$ denote the set of commodities;

$j=\{1, \ldots, \mathrm{N}\}$ denote the set of industry sectors;

$f=\{1, \ldots, F\}$ denote the set of primary factors;

$d=\{1, \ldots, \mathrm{D}\}$ denote the set of final demand.

Thus, the flow of commodities in this economy can be viewed in a matrix form:

(1) An $\mathrm{N} \times \mathrm{N}$ matrix of intermediate input-output matrix $\bar{X}$.

(2) An F $\times$ N matrix of primary factor inputs to industries $\bar{V}$.

(3) An $\mathrm{N} \times \mathrm{D}$ matrix of commodity use by the final demand activities $\bar{G}$.

From the equilibrium and market clearing conditions, the relationship between these three matrices can be motivated as follows:

$$
\bar{y}_{i}=\sum_{j=1}^{N} \bar{x}_{i j}+\sum_{d=1}^{D} \bar{g}_{i d}
$$

This identity implies that the value of output of industry $i$ which is the value of the aggregate supply of the $i$ th commodity $\bar{y}_{i}$ must be equal to the sum of the values of the jth intermediate use of that good $\bar{x}_{i j}$ and the $d$ final demand $\bar{g}_{i d}$ for that commodity.

$$
\bar{V}_{f}=\sum_{i=1}^{N} \bar{v}_{f j}
$$

This second identity implies that all the factor endowment is fully utilized by the industries.

$$
\bar{y}_{j}=\sum_{i=1}^{N} \bar{x}_{i j}+\sum_{i=1}^{F} \bar{v}_{f j}
$$

The identity above is the zero profit condition and implies that the value of the gross output of the $j$ th sector, $\bar{y}_{j}$ must be equal to the sum of the value of all inputs, primary $\left(\bar{v}_{f j}\right)$ and intermediate $\left(\bar{x}_{i j}\right)$ that the industry employs in its production.

$$
\bar{m}=\sum_{f=1}^{F} \bar{V}_{f}=\sum_{i=1}^{N} \sum_{d=1}^{D} \bar{g}_{i d}
$$

Equation (4) implies that the agent's income $\bar{m}$ is equivalent to the value she places on her factors of production $\bar{V}_{f}$ and must also be equal to her demand for commodities $\bar{g}_{i d}$, i.e., all the income must be obtained from full utilization or renting out of factors of production and the rent gained must all be used to satisfy the agent's demand for commodities.

The above equations then form the basic structure of a SAM, and it shows the arrangement of activities and flow of commodities for an economy that is in equilibrium in any benchmark period. The SAM is an array 
of input-output accounts that are dominated in the units of value of the period for which the flow in the economy are recorded, typically the currency of the benchmark year.

The structure of the SAM reflects the principle of double entry book keeping which requires that for each account, total revenue, i.e., the row total must equal total expenditure, the column total.

These identities then and the fact that they are expression of the Walrasian General Equilibrim make the SAM an ideal data base for analysis by CGE models.

\section{The CGE Model: The Cobb Douglas Economy}

As alluded to earlier, the equilibrium requirements of the SAM model make it a good data base for the CGE model solutions.

In this case, producers aim to maximize profit, which because of competition, are driven to zero while consumers aim to maximize utility under a budgetary constraint.

In the CGE model used, it is assumed that households have a Cobb-Douglas (C-D) preferences and the firms are assumed to have C-D production functions.

This is shown by equation (5) for household utility and equation (6) for industry production function below:

$$
U=A_{c} c_{1}^{\alpha_{1}} c_{2}^{\alpha_{2}} \ldots c_{N}^{\alpha_{N}}=A_{C} \prod_{i=1}^{N} c_{i}^{\alpha_{i}}
$$

In equation 5 the exponents are the share of each good in consumption such that:

$A_{C}$ is a scaling parameter.

$$
\alpha_{1}+\alpha_{2}+\cdots \alpha_{N}=1
$$

For the industry, we have:

$$
y_{j}=A_{j}\left(x_{1}^{\beta_{1}} x_{2}^{\beta_{2}} \ldots x_{N}^{\beta_{N}}\right)\left(v_{1}^{\gamma_{1}} v_{2}^{2} \ldots v_{F}^{\gamma_{N}}\right)=A_{j} \prod_{i=1}^{N} x_{i j}^{\beta_{i j}} \prod_{j=1}^{F} v_{f j}^{\gamma_{f j}}
$$

The exponents $\beta_{1 j}+\cdots+\beta_{N j}+\gamma_{1 j}+\cdots+\gamma_{N j}=1$ denote the shares of each input in the cost of production, and $A_{j}$ is a scaling factor.

As mentioned before households aim to maximize utility subject to a budget constraint. Thus, the household problem can be viewed as follows:

Subject to:

$$
\max U\left(c_{1} \ldots c_{N}\right)
$$

$$
m=\sum_{1=1}^{N} p_{i}\left(c_{i}+s_{i}\right)
$$

If households are taken as agents that maximize profit from the production of a utility of a good $U$ whose output is generated by consumption and whose price $p_{i}$ is the marginal utility of aggregate consumption, which can be treated as the numeraire price in the economy. Then equation (7) becomes:

$$
\max _{c_{i}} P_{U} U-\sum_{i=1}^{N} p_{i} c_{i}
$$

Subject to the definition of utility above and solving this problem using the Lagrangian function yields the representative agents demand function for the consumption of the ith commodity.

The solution is shown in equation (9) below:

$$
c_{i}=\alpha_{i}\left(m-\sum_{i=1}^{N} p_{i} s_{i}\right) / p_{i}
$$

And rearranging equation (9) yield the identity below:

$$
\alpha_{i}=\frac{c_{i} p_{i}}{m-\sum_{i=1}^{N} p_{i} s_{i}}
$$

This indicates that the exponents of the utility function may be interpreted as the shares of each commodity in the total value of consumption. 
Each producer maximize profit $\pi$ by choosing levels of intermediate inputs and primary factors to produce outputs, subject to the constrain of its intermediate production technology $\emptyset$.

The producer problem for the production of the $j$ th commodity is as shown in equation (10):

$$
\max _{x_{i j} v_{f j}} \pi_{j}=p_{j} y_{j}-\sum_{i=1}^{N} p_{i} x_{i j}-\sum_{f=1}^{F} w_{f} v_{f j}
$$

Subject to:

$$
y_{j}=\emptyset_{j}\left(x_{1 j}, \ldots, x_{N j} ; v_{1 j}, \ldots, v_{F j}\right)
$$

Letting each producer have C-D production technology, so that $\varnothing$ is specified according to equation (6) and solving the problem in equation (10) yield the producers $j$ 's demand for intermediate inputs of commodities.

And its demand for primary factors of inputs is:

$$
x_{i j}=\beta_{i j} \frac{p_{j} y_{j}}{p_{i}}
$$

$$
V_{f j}=\gamma_{f j} \frac{p_{j} y_{j}}{w_{f}}
$$

Rearranging equation (11) and equation (12) yields the following identities $\beta_{i j}=\frac{p_{i} x_{i j}}{p_{j} y_{j}}$ and $\gamma_{f j}=\frac{w_{f} v_{f j}}{p_{j} y_{j}}$ respectively.

These identities above are solved using similar logic for the agent's problem and give identical solutions where the exponents in the C-D production function represent the shares of their respective inputs to the production in the value of the outputs.

\section{General Equilibrium}

The equation (9), equation (11) and equation (12) are the building blocks from which a CGE model is constructed. What binds these elements together are the general equilibrium conditions developed for the SAM which must then be reformulated into a C-D format. Once these conditions are properly specified equation (9), equation (11) and equation (12) may be substituted in them to come up with the actual equations that the CGE models use to solve for equilibrium.

For the C-D economy, the conditions to be met are as follows: market clearance implies that the quantity of each commodity produced must equal the sum of the quantities of that commodity demanded by the $j$ producers in the economy as intermediate inputs to production and by the representative agent as input to consumption and saving activities. This requirement is shown in equation (13):

$$
y_{i}=\sum_{j=1}^{N} x_{i j}+c_{i}+s_{i}
$$

The quantities of primary factor $f$ used by all producers must be the sum of the agents endowment of that factor $v_{f}$, i.e.:

$$
v_{f}=\sum_{j=1}^{N} v_{f j}
$$

Zero profit implies that the value of output generated by producers $j$ must equal to the value of intermediate products used to generate that output and the payments made to agents for use of their factor endowment. This requirement is shown in equation (15):

$$
p_{j} y_{j}=\sum_{i=1}^{N} p_{i} x_{i j}+\sum_{f=1}^{F} w_{f} v_{f j}
$$

The agent's income must be equated to the value of the factors of production that she rents out to producers. This is shown in equation (16):

$$
m=\sum_{f=1}^{F} w_{f} V_{f}
$$


It is assumed that the endowment is fixed at a given instant in time for the agent. Then substituting equations (9) and (11) into equation (13) and equation (12) into equation (14) yield two excess demand vectors that define the divergence $\Delta^{C}$ between supply and demand in the market for each commodity and the divergence $\Delta^{F}$ between supply and demand in the market for each primary factor of production. The absolute values of both of these sets of differences are minimized to zero in general equilibrium. There are thus $N$ such sets of excess demand equations for the commodity market.

$$
\Delta_{i}^{C}=\sum_{j=1}^{N} \beta_{i j} p_{j} y_{j}+\alpha_{i}\left(\sum_{f=1}^{F} w_{f} V_{f}-\sum_{j=1}^{N} p_{j} s_{j}\right)+p_{i} s_{i}-p_{i} y_{i}
$$

And $F$ equations for the factor market:

$$
\Delta_{f}^{F}=\sum_{j=1}^{N} \gamma_{f j} \frac{p_{j} y_{j}}{w_{f}}-V_{f}
$$

The zero profit condition implies that the absolute value of producer's profit is minimized to zero in general equilibrium. Thus substituting equation (11) and equation (12) into the production function allows for the derivation of $N$ pseudo-excess demand functions that specify the per unit excess profit $\Delta^{\pi}$ as excess price over unit cost in each industry sector.

$$
\Delta_{j}^{\pi}=p_{j}-A_{j} \prod_{i=1}^{N}\left(p_{i} / \beta_{i j}\right)^{\beta_{i j}} \prod_{f=1}^{F}\left({ }^{w_{f}} / \gamma_{f j}\right)^{\gamma_{f j}}
$$

Lastly, the income balance condition can be reformulated in terms of the existence of income over returns to the agent's endowment of primary factors $\Delta^{m}$.

$$
\Delta^{m}=\sum_{f=1}^{F} w_{f} V_{f}-m
$$

The aim of the general equilibrium is the simultaneous minimization of $\Delta^{C}, \Delta^{F}, \Delta^{\pi}$ and $\Delta^{m}$.

\section{The Formulation, Calibration and Solution of a CGE Model}

The result of the above motivation of the CGE model is a system of $2 N+F$ equations consisting of $N$ vector of industry output or activity level $Y=\left[y_{1}, y_{2}, \ldots y_{N}\right]$, an $N$ vector of commodity prices $P=\left[p_{1}, p_{2}, \ldots p_{N}\right]$, an $F$-vector of primary factor prices $W=\left[w_{1}, w_{2}, \ldots, w_{F}\right]$ and a scalar $m$.

The aim of the solution then is to solve for a vector activity levels, commodity prices, primary factor prices and incomes, subject to all of them being greater than zero, that make the vector $\left[\Delta^{C}, \Delta^{F}, \Delta^{\pi}, \Delta^{m}\right]$ a vector of zeros.

The application of the data of the SAM in the CGE model for calculation of equilibrium come about by model calibration. As seen in the motivation of the SAM and the CGE model, the two are very similar. With the assumption of C-D economy, it is easy to see the similarity in the equations derived for both the SAM and the CGE model.

The assumption of zero profit, $\pi_{j}=0, p_{i} x_{i j}=\overline{x_{i j}}$ and $w_{f} v_{f j}=\overline{v_{f j}}$ makes the equations in the two models the same. This then is the calibration that makes the SAM fit into the CGE model. All prices are treated as index number with the value of unity in the benchmark year and all flow in the SAM treated as benchmark quantities.

This then is a simplified motivation of the usefulness of the SAM as an important data base for a CGE modeling.

The importance of this motivation is that the data of the SAM can be viewed as baseline data in which to analyze the effect of a shock on the economy in which case the changes are viewed as relative changes from the benchmarks or baseline year.

It can then be seen that the calibration of the SAM to fit into the CGE model depend on the assumption of the economy which can be at the discretion of the modeler. In this paper, a C-G economy has been assumed.

The usefulness of the CGE model as used to model policy changes and other changes of economic 
significance is that there are a large number of software that can be useful to solve the model and one that is widely used is the General Algebraic Modeling System (GAMS) which solves for the new equilibrium after the specified changes automatically. ${ }^{3}$

\section{Modeling the Economic Effect of HIV/AIDS in Swaziland}

HIV/AIDS started being a problem in Swaziland in the mid 1990's and its major impact could be measured in the year 2000 where about $38 \%$ of sexually active adults between the ages of $15-50$ were HIV positive.

Table 1 shows that the economy of Swaziland and the country's population is small meaning that major shocks like the HIV/AIDS scourge that have a major impact on the population will have significant economic repercussions.

Table 1

Summary of the Economic Indicators for Swaziland

\begin{tabular}{lc}
\hline Indicator & Average for year 2001-2008 \\
\hline Population, total (millions) & 1.17 \\
Population growth (annual \%) & 1.4 \\
Life expectancy at birth, total (years) & 31 \\
GDP (current US\$) (million) & 2,837 \\
GDP growth (annual \%) & 2.4 \\
GNI per capita, Atlas method (current US\$) & 2,600 \\
Inflation, consumer prices (annual \%) & 12.6 \\
Foreign direct investment, net inflows (\% of GDP) & 0.5 \\
Unemployment, total (\% of total labor force) & 28.2 \\
\hline
\end{tabular}

Note. Source: World Development Indicators.

Table 2 summaries the HIV/AIDS situation in Swaziland in early to mid 2000 as adapted from Henry of the Kaizer foundation (2005).

Table 2

HIV/AIDS in Swaziland

\begin{tabular}{lll}
\hline Indicator & Swaziland & Sub-Saharan Africa \\
\hline Estimated number of people living with HIV/AIDS, 2003 & 220,000 & $25,000,000$ \\
Percent of adult population estimated to be living with HIV/AIDS, 2003 & $38.8 \%$ & $7.5 \%$ \\
Estimated number of deaths due to HIV/AIDS, 2003 & 17,000 & $2,200,000$ \\
Women as percent of adults estimated to be living with HIV/AIDS, 2003 & $55 \%$ & $57 \%$ \\
$\begin{array}{l}\text { Percent of young women, ages 15-24, estimated to be living with } \\
\text { HIV/AIDS, 2001 }\end{array}$ & $31.6-47.4 \%$ & $8.9 \%$ \\
$\begin{array}{l}\text { Percent of young men, ages 15-24, estimated to be living with HIV/AIDS, } \\
\text { 2001 }\end{array}$ & $12.2-18.3 \%$ & $4.4 \%$ \\
$\begin{array}{l}\text { Estimated number of AIDS orphans, 2003 } \\
\text { Number of people estimated to be receiving antiretroviral therapy (ART), }\end{array}$ & 655,000 & $12,100,000$ \\
2005 & 8,373 (March 2005 est.) & $\begin{array}{l}500,000 \\
\text { (June 2005 est.) }\end{array}$ \\
\hline
\end{tabular}

\footnotetext{
${ }^{3}$ Another model that uses the concepts of partial equilibrium is the GTAP (Global Trade Analysis Project) that is used to model mostly trade policies.
} 
The high HIV/AIDS rate in the country will inevitable have economic implication and the aim then is to determine which areas of the economy are likely to be affected by the disease and what are the economic significance of these on the overall economy by use of SAM and CGE Models.

Table 3 shows a possible macro SAM matrix that can be applicable to Swaziland and this matrix has been adapted from the framework of that of Malawi by Chulu (2001).

Table 3

A Possible Social Accounting Matrix (SAM) Framework for Swaziland

\begin{tabular}{|c|c|c|c|c|c|c|c|c|c|c|c|}
\hline & Activities & Commodities & Factors & Enterprise & Households & $\begin{array}{l}\text { Recurrent } \\
\text { government }\end{array}$ & $\begin{array}{l}\text { Government } \\
\text { investment }\end{array}$ & \begin{tabular}{|l|} 
Savings/ \\
investments
\end{tabular} & $\begin{array}{l}\text { Changes in } \\
\text { stock }\end{array}$ & $\begin{array}{l}\text { Rest of the } \\
\text { world }\end{array}$ & Total \\
\hline Activities & & $\begin{array}{l}\text { Marketed } \\
\text { production }\end{array}$ & & & & & & & & & Total sales \\
\hline Commodities & $\begin{array}{l}\text { Intermediate } \\
\text { consumption }\end{array}$ & & & & $\begin{array}{l}\text { Final } \\
\text { household } \\
\text { consumption }\end{array}$ & $\begin{array}{l}\text { Government } \\
\text { final } \\
\text { recurrent } \\
\text { consumption }\end{array}$ & $\begin{array}{l}\text { Government } \\
\text { expenditure } \\
\text { on } \\
\text { investment }\end{array}$ & \begin{tabular}{|l|} 
Private \\
investments
\end{tabular} & $\begin{array}{l}\text { Changes in } \\
\text { stocks }\end{array}$ & $\begin{array}{l}\text { Exports } \\
\text { (FOB) }\end{array}$ & $\begin{array}{l}\text { Domestic } \\
\text { demand }\end{array}$ \\
\hline Factors & $\begin{array}{l}\text { Value added } \\
\text { at factor cost }\end{array}$ & & & & & & & & & & $\begin{array}{l}\text { Value added } \\
\text { at factor cost }\end{array}$ \\
\hline Enterprise & & & & $\begin{array}{l}\text { Value } \\
\text { added } \\
\text { capital }\end{array}$ & & & & & & & $\begin{array}{l}\text { Enterprise } \\
\text { income }\end{array}$ \\
\hline Household & & & $\begin{array}{l}\text { Value } \\
\text { added } \\
\text { labour }\end{array}$ & $\begin{array}{l}\text { Distributed } \\
\text { profit }\end{array}$ & & $\begin{array}{l}\text { Subsidies and } \\
\text { social security }\end{array}$ & & & & & $\begin{array}{l}\text { Household } \\
\text { income }\end{array}$ \\
\hline $\begin{array}{l}\text { Recurrent } \\
\text { government }\end{array}$ & & $\begin{array}{l}\text { Sales, import } \\
\text { duties }\end{array}$ & $\begin{array}{l}\text { Factor } \\
\text { tax }\end{array}$ & $\begin{array}{l}\text { Cooperate } \\
\text { tax }\end{array}$ & $\begin{array}{l}\text { Individual } \\
\text { income tax }\end{array}$ & & & & & \begin{tabular}{|l} 
Grant and \\
transfer from \\
ROW
\end{tabular} & $\begin{array}{l}\text { Government } \\
\text { recurrent } \\
\text { receipts }\end{array}$ \\
\hline $\begin{array}{l}\text { Government } \\
\text { investments }\end{array}$ & & & & & & & & \begin{tabular}{|c|} 
Government \\
investments
\end{tabular} & & & $\begin{array}{l}\text { Government } \\
\text { investments }\end{array}$ \\
\hline $\begin{array}{l}\text { Savings/ } \\
\text { investment }\end{array}$ & & & & $\begin{array}{l}\text { Enterprise } \\
\text { savings }\end{array}$ & $\begin{array}{l}\text { Household } \\
\text { savings }\end{array}$ & $\begin{array}{l}\text { Government } \\
\text { savings }\end{array}$ & & & & $\begin{array}{l}\text { Loans from } \\
\text { ROW } \\
\text { development } \\
\text { account } \\
\end{array}$ & Savings \\
\hline $\begin{array}{l}\text { Changes in } \\
\text { stock }\end{array}$ & & & & & & & & $\begin{array}{l}\text { Changes in } \\
\text { stock }\end{array}$ & & & $\begin{array}{l}\text { Changes in } \\
\text { stock }\end{array}$ \\
\hline $\begin{array}{l}\text { Rest of the } \\
\text { world }\end{array}$ & & Imports (CIF) & $\begin{array}{l}\text { Factor } \\
\text { payment } \\
\text { abroad }\end{array}$ & $\begin{array}{l}\text { Interest } \\
\text { payments } \\
\text { etc }\end{array}$ & & & & & & & $\begin{array}{l}\text { Payments } \\
\text { abroad }\end{array}$ \\
\hline Total & Gross output & $\begin{array}{l}\text { Total } \\
\text { commodity } \\
\text { supply }\end{array}$ & \begin{tabular}{|l} 
Value \\
added at \\
factor \\
cost
\end{tabular} & $\begin{array}{l}\text { Enterprise } \\
\text { expenditure }\end{array}$ & $\begin{array}{l}\text { Household } \\
\text { expenditure }\end{array}$ & $\begin{array}{l}\text { Government } \\
\text { expenditure }\end{array}$ & $\begin{array}{l}\text { Government } \\
\text { investments }\end{array}$ & Investments & $\begin{array}{l}\text { Changes in } \\
\text { stock }\end{array}$ & $\begin{array}{l}\text { Receipts from } \\
\text { abroad }\end{array}$ & \\
\hline
\end{tabular}

From the SAM matrix, we then analyze how HIV/AIDS can affect this equilibrium using possible identities that can be disturbed. To effectively analyze the effect of the HIV/AIDS, a macroeconomic SAM is ideal since it is best highlights the economic areas affected in a broader country wide perspective. In examining poverty in a country, which has direct application in the analysis of the impact of HIV/AIDS, Khan (2007) used the following aspects:

(1) Classification of households by socio-economic characteristics;

(2) Understanding the income generation process by which the households receive their incomes;

(3) Pinpointing the distributional mechanisms;

(4) Comprehending the household consumption patterns;

(5) Linking household income and consumption to social capabilities and functions;

(6) Estimation of the resource generating capacity and resource absorbing capacity of the households.

Further to the above ideas then, to analyze the economic impact of HIV/AIDS in Swaziland it is important that the country develops a SAM for the year 1990 (which will act as the base year) when the effect of the disease was basically insignificant and then to simulate various outcomes due to the disease in the macro 
economy and then look at the ripple effect of this throughout the economy. The effect of HIV/AIDS on the economy then can be viewed as having cross-effects a multiplier process whereby an injection into one part of the system has repercussions on other parts. In this case, the HIV/AIDS effect will be viewed as an exogenous shock affecting the matrix equilibrium in an open loop manner.

Possible economic areas that could be affected by an AIDS outbreak in the macro economy SAM are as follows.

\section{Household Consumption Expenditure}

The household disposable income is expected to be affected by the disease spread. In this case, it is expected that household income will decrease due to the loss of working individual. This income is used to buy commodities, thus reduced household income is also expected to have an effect on the demand for commodities in the economy.

More income is also used for medical care instead of satisfying demand for household commodities. This also affects household savings and investments. This means that from the above SAM, the household expenditure is supposed to reflect the effect of the disease in the economy, and using the CGE equilibrium requirements, the effect of this can be determined in the whole economy.

\section{Productivity}

HIV/AIDS is expected to have a negative impact on the productivity of the country. This is more so because it targets the productive age groups. This means that the factors of production that the country uses, which is labor will be reduced. This will also have a tendency of reducing the wages that the factors of production could earn, which in turn reduces disposable income and demand for household consumption. This is aggravated by the diversion of disposable income into medical cost and caring for orphans and vulnerable children who are still not able to earn any income. This then means that much as demand for commodities is expected to go down, the supply of commodities is also expected to be negatively affected.

\section{Government Revenue}

Government revenue is also expected to be affected in that the disease is prevalent amongst working and able individuals. This means then that there are less people paying taxes meaning that the factor tax is affected. From an analysis of a SAM by Lofgren, Robinson and Thurlow (2002) government revenue identity can be viewed as shown below:

$$
\begin{aligned}
\text { Government revenue }= & \text { direct taxes from institutions }+ \text { direct taxes from factors }+ \\
& \text { value added taxes }+ \text { activity tax }+ \text { import tariffs }+ \text { export taxes }+ \\
& \text { sales taxes }+ \text { factor income }+ \text { transfer from ROW }
\end{aligned}
$$

From the above equation, it is easy to see that the government revenue will be affected since there will be reduced factor income and taxes from factors, which will have an effect of affecting productivity, investments and savings in the economy.

The equilibrium for government revenue is shown below:

$$
\text { Government revenue }=\text { government expenditure }+ \text { government savings }
$$

Government expenditure is expected to shift this equilibrium in that more money is diverted from savings and investments into health care for the affected individuals in the population who remain unproductive.

Bollinger (1999) has discussed the economic impact of HIV as having negative effects on labor supply, households, agriculture, firms and education and exerting pressure on the health sector. All these effects can be 
analyzed quantitatively as this paper has highlighted.

\section{Discussion and Conclusion}

This paper has revisited the motivation of the SAM and CGE modeling as was developed by Wing (2003). It then looked at a possible macroeconomic SAM for a country like Swaziland. Whether the data is extrapolated from a microeconomic SAM or a macroeconomic SAM, similar equilibrium conditions hold as has been developed from the paper by.

To motivate the effect of HIV/AIDS on the economy, the areas that are most likely to be affected by the disease can be disaggregated while keeping the rest of the data of the SAM that is less likely to be affected directly relatively aggregated.

The discussion has shown the importance of a SAM for Swaziland and indeed any country that does not have it and how it can be important to analyze any shock that is of economic significance, as the case of HIV/AIDS in Swaziland. It is hoped that this paper will form the framework and motivation for the development of a SAM for that country which can then extend the arguments presented in this paper into a concise empirical analysis.

Identification and quantification of the economic areas most affected by this scourge can also inform policy since intervention measures can be target to the areas that the disease has more economic impact, e.g., increased expenditure on education and human resource development to increase productivity.

\section{References}

Alderman, I., \& Robinson, S. (1986). Proceedings issues. American Jounal of Economics, 68(5), 1196-1207.

Bollinger, L., \& Stover, J. (1999). The economic impact of AIDS in Swaziland. The policy project. The Futures Group International in collaboration with: Research Triangle Institute (RTI) and The Centre for Development and Population Activities (CEDPA).

Central Statistics Office. (2000). The government of Swaziland statistics. Ministry of Planning and Economic Development.

Chulu O., \& Wobst P. (2001). A 1998 social accounting matrix for Malawi (Agricultural Policy Unit, Bunda College of Agriculture. TMD Discussion paper No. 69).

FAO. (2009). FAO agricultural outlook. Retrieved from http://www.fao.org

Khan, H. (2007). Social accounting matrix: A very short introduction (Working paper CIRJE-F-477, University of Denver).

Lofgren, H., Robinson, S. \& Thurlow, J. (2002). Macro and Micro effects of recent and potential shocks to copper mining in Zambia. International Food Policy Research Institute. TMD Discussion Paper No. 99. Washington, D.C.

McDonald, S., Kirsten, J. F., \& Van Zyl, J. (1997). A social accounting matrix accounting matrix for modeling agricultural policy reform in south. Agrekon, 36(4).

The Kaizer. H. J. Family Foundation. (2005). The HIV/AIDS epidemic in Swaziland. HIV Policy Fact Sheet. 2400 Sand Hill Road, Menlo Park, CA 94025.

Wing. S. I. (2005). Computable general equilibrium models and their use in economy wide policy analysis: Everything you ever wanted to know but were afraid to ask. Centre for Energy and Environmental Studies Boston University and Joint Program on Science and Policy of Global Change. Massachusetts Institute of Technology.

Word Development Indicators. (2009). Retrieved from http://www.worldbank.org/ 